Assessing online and offline adolescent social skills:

Development and validation of the Real and Electronic Communication

Skills questionnaire (RECS)

Gregory Mantzouranis • Sophie Baudat • Grégoire Zimmermann

G. Mantzouranis $\bowtie \bullet$ Sophie Baudat • Grégoire Zimmermann

Family and DevelOpment Research Center (FADO), Institute of Psychology, University of Lausanne, Switzerland

E-mail: Gregory.Mantzouranis@chuv.ch

This is a post-print of an article in press in Cyberpsychology, Behavior, and Social Networking.

The final publication will be available from Mary Ann Liebert, Inc., publishers: https://doi.org/10.1089/cyber.2018.0655

Please note that the published version has undergone minor additional editing in style and content. Please cite as:

Mantzouranis, G., Baudat, S., \& Zimmermann, G. (in press). Assessing online and offline adolescent social skills: Development and validation of the Real and Electronic Communication Skills questionnaire (RECS). Cyberpsychology, Behavior, and Social Networking. https://doi.org/10.1089/cyber.2018.0655 


\begin{abstract}
Studies examining the associations between Internet use and social skills are increasingly frequent. However, most of them only evaluate offline social skills and consider them as equivalents to online social skills. So far, no instrument allowed differentiating social skills depending on online versus offline contexts. The present study aimed to develop and validate the Real and Electronic Communication Skills questionnaire (RECS), a new measure evaluating several dimensions of social skills in two different contexts (i.e., face-to-face and computer-mediated communication). Results of exploratory and confirmatory factor analyses among a sample of 657 adolescents and young adults (mean age $=17.68$ years; $67 \%$ female) showed that the best fitting model for each context is a bifactor solution, with one general factor (Social Competence) and four specific factors (Sociability, Emotion Decoding, Disclosure, and Assertiveness). Each specific factor was differentially correlated with theoretically relevant subscales of the Social Skills Inventory, confirming the external validity of the RECS. The RECS is the first instrument allowing not only to assess social competence in online settings, but also to quantify the relationships between offline social skills and their online counterpart. Given its ease of use and its brevity, the RECS is a useful and promising instrument to capture social skills in both online and offline contexts.

Keywords: scale development, social skills, computer mediated communication, contextual differences, online/offline comparison
\end{abstract}


Is it possible to be more sociable when interacting with a friend on Facebook rather than face-to-face? Since the rapid spread of the Internet, a growing number of studies suggested that social skills may be expressed differently when people interact in online versus offline contexts. Indeed, many theories suggest that a distinction should be made between offline and online social interactions. Face-to-face $(\mathrm{FtF})$ and computer-mediated communication (CMC) contexts differ from each other, for instance, in terms of their number and type of cue systems (e.g., verbal, non-verbal or paraverbal), their degree of instant feedback, or in terms of the personal focus they require from the user (e.g., amount of time to formulate a response; ${ }^{1}$ ). Consequently, a person could be more (or less) socially skilled depending on whether he or she communicates FtF versus through CMC.

Given that social skills are considered as context-sensitive ${ }^{2,3}$, their assessment among Internet users would be comprehensive by addressing not only the context of FtF interaction, but also the context of CMC. Surprisingly, the majority of studies exploring the associations between Internet use and social skills used measures intended for either FtF (e.g., ${ }^{4,5-8}$ ) or CMC interactions (e.g., ${ }^{9}, 10,11$ ). Only a few studies evaluated specific social skills, such as self-disclosure, in both contexts simultaneously (e.g., ${ }^{12,13}$ ). The purpose of the present study was to fill this gap by developing a self-report questionnaire, the Real and Electronic Communication Skills questionnaire (RECS), which simultaneously assesses multiple dimensions of social skills in both FtF and CMC contexts.

\section{Dimensions of Social Skills}

One major difficulty in developing a measure of social skills resides in the relatively broad definition of this construct. Indeed, the conceptualization of social skills varies drastically depending on the research area (psychology, sociology, medicine, management, etc.), or on the school of thought ${ }^{14}$. Given the lack of a universal definition of this concept, our approach consisted of selecting the most important dimensions of social skills that occur within both 
FtF and CMC contexts. Hence, these dimensions mainly focus on interpersonal relations, thereby excluding other concepts that are also considered as social skills (e.g., selfmanagement, academic or compliance skills; ${ }^{15}$ ). In line with a recent review of literature by Reich $^{16}$, we found that the following six dimensions were frequently used in previous research examining social skills in $\mathrm{FtF}$ and $\mathrm{CMC}$ contexts: (a) Assertiveness, (b) Initiation of Interactions, (c) Self-disclosure, (d) Sociability, (e) Expression of Emotions, and (f) Emotion Decoding. From a theoretical point of view, these skills are considered as essential ingredients for good interpersonal relationships in both online or offline contexts. Even if their expression is context-dependant ${ }^{2}$, their function remains the same regardless of the environment within which social interactions take place. Specifically, these skills allow people to create new interactions, to maintain and to manage these relations and, more generally, to communicate appropriately ${ }^{17}$.

\section{Assertiveness}

The definition of assertiveness includes two response classes: positive assertion and negative or conflict assertion ${ }^{18}$. Positive assertion includes aspects such as the expression of positive emotions, the acceptance of compliments, or the ability to initiate, sustain or terminate social interactions. Negative or conflict assertion consists of making reasonable requests, asking others to change their behavior, or expressing disagreement. In the present study, we considered the components of initiating interactions (for positive assertion), as well as the aspects of giving personal opinions even if they are unpopular, expressing disagreement, and refusing unreasonable requests (for conflict assertion).

\section{Initiation of Interactions}

The ability to initiate interactions consists of taking the initiative of starting a new interaction with someone (e.g., speaking to a stranger, suggesting to a friend to engage in a new activity). As this skill involves some components of initiative, it was frequently 
considered as a response class of assertiveness in different theoretical conceptualizations ${ }^{19-21}$ and in various assertiveness inventories ${ }^{22,23}$. However, factor analyses carried out by Buhrmester, Furman, Wittenberg, and Reis ${ }^{24}$ on several domains of interpersonal competence indicated that skills of initiation and conflict assertion are relatively independent constructs. Given this assumption, we considered them as separate skills.

\section{Self-Disclosure}

In line with Tardy and Dindia ${ }^{25}$, we considered self-disclosure as the intentional divulgation of personal information by verbal means, that is, a behavior that implies taking a certain amount of risks. Specifically, we focused on the disclosure of highly risky information by examining the "core layer" of self-disclosure, namely the divulgation of intimate information about self (e.g., values, needs, fears and personal beliefs) ${ }^{26}$.

\section{Sociability}

Sociability refers to the tendency to prefer affiliating and interacting with others instead of being alone. It involves the ability to enter a peer group and to integrate one's behavior with the ongoing activity, including meeting strangers and making new friends 17,27 .

\section{Expression of Emotions and Emotion Decoding}

Our last two dimensions of interest - expression of emotions and emotion decoding are considered as sub-components of the broader construct of emotional intelligence ${ }^{28}$. These concepts represent one of the most elementary forms of communication ${ }^{29}$. Contrary to the dimensions presented above, expressing and decoding emotions are predominantly based on non-verbal or paraverbal cues, such as facial expression, tone of voice or bodily movements. For these reasons, these two dimensions are usually studied in the realm of non-verbal behavior ${ }^{30}$.

\section{Method}

\section{Participants and Procedure}


Two samples of adolescents and young adults were used in this study $(N=657)$. Sample $1\left(n_{1}=358 ; 81.7 \%\right.$ female $)$ allowed us to identify the factor structure of our initial 100-item questionnaire and to select the best fitting items for the final form. This sample was composed of participants recruited among apprentices and university students in the Frenchspeaking part of Switzerland. Their mean age was 21.66 years $(S D=3.84$ years; $90 \%$ confidence interval range $=18-28$ years $)$. Sample $2\left(n_{2}=299 ; 49.8 \%\right.$ female $)$ was used to confirm the factor structure of the final form of the RECS. It was composed of adolescents recruited in French-speaking middle schools with a mean age of 12.93 years $(S D=0.86$ years; $90 \%$ confidence interval range $=12-14$ years). Finally, we used the total sample of this study ( $N=657 ; 67 \%$ female) to assess internal consistency as well as external validity of our measure. Mean age for the total sample was 17.77 years $(S D=5.23,90 \%$ confidence interval range $=12-26$ years). Most respondents reported using the Internet every day for private purposes $(72.2 \%)$ and to communicate online with people they had previously met offline (81.6\%). In line with socio-economic levels generally observed in Switzerland ${ }^{31}$, socioeconomic status measured with the IPSE ${ }^{32}$ indicated that $58 \%$ of the participants came from middle to upper class families. Our study was conducted in compliance with the Ethical Code of the Swiss Psychological Society.

\section{Measures}

Real and Electronic Communication Skills questionnaire (RECS). The initial version of the RECS consisted of a 100-item questionnaire and comprised two subscales referring respectively to $\mathrm{FtF}$ and $\mathrm{CMC}$ contexts. First, the Real Communication Skills (RCS) subscale aimed to evaluate dimensions of social skills as used in $\mathrm{FtF}$ social interactions. Second, the Electronic Communication Skills (ECS) subscale focused on the evaluation of the same dimensions of social skills, but as used in text-based, CMC social interactions. Each subscale assessed the following six dimensions of social skills: (a) Expression of Emotions, 
(b) Emotion Decoding, (c) Sociability, (d) Initiation of Interactions, (e) Self-disclosure, and (f) Assertiveness. Items for each dimension were either created or derived from existing instruments assessing social skills in FtF contexts. Specifically, items of the Assertiveness dimension were developed on the basis of the Rathus' Assertiveness Schedule ${ }^{23,33}$, and of the Assertiveness subscale of the Questionnaire about Interpersonal Difficulties for Adolescents $\left(\mathrm{QIDA} ;{ }^{34}\right)$. Items of the Initiation of Interactions dimension, of the Sociability dimension and of the Expression of Emotions and Emotion Decoding dimension were respectively inspired by the Initiation subscale of the Interpersonal Competence Questionnaire (ICQ; ${ }^{24}$ ), by Cheek and Buss' ${ }^{27}$ Sociability scale, and by the Positive and Negative Expressivity subscales of the Berkeley Expressivity Questionnaire ${ }^{35}$. Responses were rated on a five-point Likert scale $(1$ = strongly disagree, 5 = strongly agree $)$.

Social Skills Inventory (SSI). The SSI ${ }^{36,37}$ is one of the most widely used questionnaires for evaluating basic social skills. This 90-item questionnaire assesses three dimensions of basic social communication skills (expressivity, sensitivity and control) on two levels (emotional and social), for a total of six subscales. The dimensions of expressivity, sensitivity and control refer to sending, receiving and monitoring messages, respectively. The emotional level concerns non-verbal messages dealing with affects, attitudes and status, whereas the social level relates to verbal messages, social discourse and social norms. Responses were rated on a 5-point Likert scale $(1=$ not at all like me, $5=$ exactly like me $)$. In the current study, Guttman-Cronbach's alpha was .82 for the total scale and ranged from .67 to .85 for the different subscales. We used this measure to examine the nomological validity of RECS subscales and to investigate the associations of different social skills with RECS dimensions.

\section{Analysis Strategy}


First, we performed two principal components analyses (PCA) on Sample 1: the first one allowed us to explore the factor structure of each subscale and to identify their most informative items; the second one allowed us to examine and to describe their new structure. Second, we conducted a confirmatory factor analysis (CFA) on Sample 2 to confirm the factor structure of our two subscales, and to identify the best structural model for the whole instrument. We assessed the internal consistency reliability for the dimensions of each subscale using Guttman-Cronbach's alpha ${ }^{38,39}$ and McDonald's ${ }^{40}$ omega coefficients. Finally, we tested the nomological validity of the RECS by comparing its dimensions with dimensions of the SSI. Analyses were performed using R-Software 3.1.0 ${ }^{41}$.

\section{Results and Discussion}

\section{Principal Component Analyses}

To identify latent factors for each of the two subscales of the RECS, we performed PCAs with varimax rotation on Sample 1. The Kaiser-Meyer-Olkin values were excellent for the RCS $(\mathrm{KMO}=.83)$ and the ECS $(\mathrm{KMO}=.88)$, indicating sampling adequacy and good factorability of both subscales.

As a first step, we roughly refined the initial item pool. For the first PCA, we examined the scree plots to decide on the number of factors to extract. Contrary to the hypothesized six-factor structure, the scree plots suggested a four-factor solution for both RCS and ECS subscales. These four-factor solutions accounted for 33\% and 38\% of the variance, respectively. In both subscales, our expected dimensions of Self-disclosure and Expression of Emotions were merged into a single factor named Self-disclosure. This is congruent with a somewhat broader definition of self-disclosure that includes the disclosure

of feelings ${ }^{25}$. The dimensions of Sociability and Initiation of Interactions were also grouped into a single Sociability factor. Indeed, initiation of interactions can be considered as a specific part of the broader concept of sociability, as it is often a necessary first step to 
achieve the exploratory activity inherent in the sociability concept. To summarize, the final four factors for each subscale were labeled: (a) Sociability, (b) Self-disclosure, (c) Emotion Decoding, and (d) Assertiveness.

As a second step, we reduced the number of items of each subscale by selecting those with the highest loading on each factor, thereby excluding items loading on more than one factor (cross-loadings) or items loading on unexpected factors. Among the items meeting these criteria, we selected those that had corresponding items in both subscales (RCS and ECS). Each factor consisted of five items, except for the Assertiveness factor which included only three items because of a large number of cross-loadings. In sum, the final version of the RECS is a 36-item questionnaire composed of two subscales: one assessing social skills in FtF contexts (RCS), the other in CMC contexts (ECS). Each subscale consists of 18 items mirroring the items of the other subscale and measuring four dimensions of social skills (i.e., Sociability, Self-disclosure, Emotion Decoding, and Assertiveness).

Finally, we ran PCAs separately on each subscale to examine their new structure. Results are presented in Table 1. As these 18-item forms were intended to be the final ones, we used several statistical procedures to determine the optimal number of factors to extract: scree plots, Horn's parallel analysis, and the Very Simple Structure procedure ${ }^{42}$. All three methods converged on a four-factor solution for each subscale. The varimax-rotated solutions explained respectively $51 \%$ and $48 \%$ of the variance for the RCS and the ECS.

- Table 1 -

\section{Confirmatory Factor Analyses}

To confirm and clarify the internal structure of the RECS, we conducted a confirmatory factor analysis (CFA) on Sample 2. First, we compared alternative models for both subscales of the RECS. Model 1 represents the four independent factor model (Sociability, Self-disclosure, Emotion Decoding, Assertiveness). Model 2 allows latent 
factors to covary. As the explained variance in our PCAs was not very high (around 50\%) and given that the communalities of the items were sufficiently important, we assumed the existence of a general construct for each subscale. This led us to examine two alternative models (Model 3 and Model 4). Model 3 supposes a hierarchical structure with a secondorder general factor, whereas Model 4 is a bifactor model in which a general latent factor underlies all of the items, alongside four domain specific factors (Sociability, Self-disclosure, Perception of emotions, Assertiveness), that underlie four subsets of items. The second-order model (Model 3) differs from the bifactor model (Model 4) in that the former assumes that the domain specific factors are correlated, and that the higher order factor accounts for the relationship between the lower order factors ${ }^{43}$. Conversely, the bifactor model (Model 4) supposes that the general factor accounts for the communality of the items, and that each specific factor accounts for unique variance in its own set of items.

The fit indices for these four models are presented in Table 2. The bifactor model (Model 4) provides an excellent fit for both subscales. Our results also indicate that the bifactor models provides a statistically significant improvement in terms of degrees of freedom and model chi-square in comparison with the alternative models. These results confirm the four-factor solution based on the exploratory factor analysis of each subscale, and suggest the existence of a general factor accounting for the specific context of each subscale. The general factors of the RCS and of the ECS represent the general constructs of offline and online social competence, respectively.

- Table 2 -

After identifying the best structure for each subscale, we compared alternative models of relationships between these subscales. Model 5 (Table 2) assumes complete independence between both subscales. Model 6 allows each group factor of a subscale to covary with the similar group factor of the other subscale (e.g., the Sociability factor of the RCS was allowed 
to covary with the Sociability factor of the ECS), whereas Model 7 allowed an additional covariance between the two general factors. Only Model 7 showed acceptable fit, with satisfactory RMSEA and SRMR values. CFI value was lower, but incremental fit indices such as the CFI are known to penalize slightly distorted models, when their main loadings are lower than .70, which is the case with our data ${ }^{44}$. Additionally, compared to the alternative models, Model 7 presented a statistically significant improvement in terms of degrees of freedom and model chi-square. To summarize, the total structure of the RECS matches our expectations in that each latent factor estimated in one context - be it a general or a specific factor - shares some common variance with the same latent factor estimated in the other context (see Figure 1). Moreover, each general and specific factor seems to have some core characteristics that are expressed differentially depending on the context. This is congruent with the idea that interactions are determined conjointly by personal characteristics (e.g., social skills, motives or attitudes) and by contextual parameters (see for example, ${ }^{45}$ ).

- Figure 1 -

\section{Internal Consistency}

Reliability indices were good for the whole RCS and for its dimensions (Table 3). For the whole ECS, reliability indices were equally good, with indices of some dimensions somewhat lower (e.g., Assertiveness). Knowing that the alpha is always lower in scales with few items, these relatively low levels are acceptable ${ }^{46}$.

- Table 3 -

\section{Nomological Validity}

The correlations between the two subscales of the RECS and the six subscales of the SSI are shown in Table 3. The total scores of the RCS and the ECS have both positive and large statistically significant correlations with the total score of the SSI, which denotes a good relationship between RECS' subscales and basic social skills. Moreover, we found that each 
dimension of the RECS has a differential relationship with the subscales of the SSI. Each subscale of the RECS had the highest correlations with a theoretically relevant subscale of the SSI: Sociability was linked with Social Expressivity, Disclosure with Emotional Expressivity, Emotion Decoding with Emotional Sensitivity and Assertiveness with Social Control. Finally, the various dimensions of the SSI were more strongly correlated with the RCS subscales than with the ECS ones. This result is not surprising as the SSI measures social skills in FtF interactions.

\section{Conclusion}

The purpose of this study was to develop and validate a multidimensional measure of social communication skills applicable to CMC and FtF contexts. The RECS has been subject to a thorough and stringent validation procedure, and the final form of the questionnaire showed good psychometric properties. Its complex factor structure allowed accounting for both individual and contextual factors. Internal consistency indices were satisfactory, given the conciseness of the questionnaire. The external validity of the RECS and its different subscales, as measured by the correlations with the SSI, was also good and confirmed the place of the RECS in the nomological network. Thus, the results of this study provide preliminary evidence of the factorial, reliability, and nomological validity of the RECS. Although promising, the present study is limited. First, given that Sample 1 was mainly composed of females $(81.7 \%)$, we cannot exclude that the initial item selection was biased. In fact, previous research has shown that females are more likely to view affectively oriented social skills as slightly more important compared to males ${ }^{47}$. Nevertheless, the structure of the RECS has been confirmed by the CFAs using the more balanced Sample 2. Second, given that the present study was conducted in the French-speaking part of Switzerland, it is unclear to what extent the use of the RECS could be generalized to other cultural contexts. 
Today, many adults assume that youth are necessarily experts in new Internet technologies, but there is important variation in adolescents' experience and use ${ }^{48}$. Despite these differences, interactions between adolescents are increasingly mediated through new Internet technologies ${ }^{49}$. This increase of online peer interactions has generally led to growing concerns about the effects of the Internet on young people's socialization ${ }^{50}$. The evaluation of these effects should not be limited to a single aspect of socialization, but should be considered more broadly. In a recent literature review, Reich ${ }^{16}$ points out that, to date, no studies investigated social competence in online spaces, nor identified links between online and offline social competence. The RECS is the first questionnaire allowing a one-to-one comparison of several dimensions of social skills in FtF versus CMC contexts. Additionally, questions arise as to whether online social competence may be transferred to offline social competence, or whether different contexts (i.e., online and offline) may be associated with differences in patterns of social competence ${ }^{51}$. In this regard, the RECS is the first tool to create a bridge between the overarching constructs of offline and online social competence as well as to quantify the relationship between offline and online social skills. As young people keep being more and more connected ${ }^{52}$, this bridge may allow future studies to investigate the importance of social competence in online contexts.

\section{Author Disclosure Statement}

No competing financial interests exist. 


\section{References}

1. Joinson AN. (2003) Understanding the psychology of Internet behaviour: Virtual worlds, real lives. New York, NY: Palgrave MacMillan.

2. Argyle M, Furnham A, Graham JA. (1981) The effect of the situation on behaviour. In: Argyle M, Furnham A, Graham JA, eds. Social situations. Cambridge: Cambridge University Press; 1981. pp. 41-67.

3. McFall RM. A review and reformulation of the concept of social skills. Behavioral Assessment. 1982;4(1):1-33.

4. Caplan SE. A social skiil account of problematic Internet use. Journal of Communication. 2005;55(4):721-36.

5. Chan TH. Facebook and its effects on users' empathic social skills and life satisfaction: A double-edged sword effect. Cyberpsychology, Behavior, and Social Networking. 2014;17:276-80.

6. Engelberg E, Sjöberg L. Internet use, social skills, and adjustment. CyberPsychology \& Behavior. 2004;7(1):41-7.

7. Harman JP, Hansen CE, Cochran ME, Lindsey CR. Liar, liar: Internet faking but not frequency of use affects social skills, self-esteem, social anxiety, and aggression.

CyberPsychology \& Behavior. 2005;8(1):1-6.

8. Valkenburg PM, Peter J. Adolescents' identity experiments on the internet:

Consequences for social competence and self-concept unity. Communication Research. 2008;35(2):208-31.

9. Peter J, Valkenburg PM, Schouten AP. Characteristics and motives of adolescents talking with strangers on the Internet. CyberPsychology \& Behavior. 2006;9(5):526-30. 10. Trepte $S$, Reinecke $L$. The reciprocal effects of social network site use and the disposition for self-disclosure: A longitudinal study. Computers in Human Behavior. 2013;29:1102-12.

11. Wang J-L, Jackson LA, Gaskin J, Wang H-Z. The effects of Social Networking Site (SNS) use on college students' friendship and well-being. Computers in Human Behavior. 2014;37:229-36.

12. Antheunis ML, Valkenburg PM, Peter J. Computer-mediated communication and interpersonal attraction: An experimental test of two explanatory hypotheses.

CyberPsychology \& Behavior. 2007;10(6):831-6.

13. Knop K, Öncü JS, Penzel J, et al. Offline time is quality time. Comparing withingroup self-disclosure in mobile messaging applications and face-to-face interactions. Computers in Human Behavior. 2016;55(Part B):1076-84.

14. Wilson SR, Sabee CM. (2003) Explicating communicative competence as a theoretical term. In: Greene JO, Burleson BR, eds. Handbook of communication and social interaction skills. New York: Routledge; 2003. pp. 3-50.

15. Caldarella P, Merrell K. Common dimensions of social skills of children and adolescents: A taxonomy of positive behaviors. School Psychology Review. 1997;26(2):26478.

16. Reich SM. Connecting offline social competence to online peer interactions.

Psychology of Popular Media Culture. 2017;6(4):291-310.

17. Semrud-Clikeman M. (2007) Development of social competence in children. In:

Semrud-Clikeman M, ed. Social competence in children. New York: Springer; 2007. pp. 1137.

18. Hargie O. (2011) Skilled interpersonal communication. New York: Routledge.

19. Galassi MD, Galassi JP. Assertion: A critical review. Psychotherapy: Theory, Research, and Practice. 1978;15(1):16-29.

20. Lazarus AA. On assertive behavior: A brief note. Behavior Therapy. 1973;4(5):697-9. 
21. Schroeder HE, Rakos RF, Moe J. The social perception of assertive behavior as a function of response class and gender. Behavior Therapy. 1983;14(4):534-44.

22. Arrindell WA, Bridges KR, van der Ende J, et al. Normative studies with the Scale for Interpersonal Behaviour (SIB): II. US students: A cross-cultural comparison with Dutch data. Behaviour Research and Therapy. 2001;39(12):1461-79.

23. Rathus SA. A 30-item schedule for assessing assertive behavior. Behavior Therapy. 1973;4(3):398-406.

24. Buhrmester D, Furman W, Wittenberg MT, Reis HT. Five domains of interpersonal competence in peer relationships. Journal of Personality and Social Psychology. 1988;55(6):991-1008.

25. Tardy CH, Dinida K. (2006) Self-disclosure: Strategic revelation of information in personal and professional relationships. In: Hargie O, ed. The handbook of communication skills. New Yorl: Routledge; 2006. pp. 229-66.

26. Altman I, Taylor D. (1973) Social penetration: The development of interpersonal relationships. New York: Holt, Rinehart and Winston.

27. Cheek JM, Buss AH. Shyness and sociability. Journal of Personality and Social Psychology. 1981;41(2):330-9.

28. Mayer JD, Roberts RD, Barsade SG. Human abilities: Emotional intelligence. Annual Review of Psychology. 2008;59:507-36.

29. Schmidt KL, Cohn JF. Human facial expressions as adaptations: Evolutionary questions in facial expression research. American Journal of Physical Anthropology. 2001;116(33):3-24.

30. Planalp S, DeFrancisco VL, Rutherford D. Varieties of cues to meotion in naturally occurring situations. Cognition and Emotion. 1996;10(2):137-53.

31. Federal Statistical Office. Economic and social situation of the population. Federal Statistical Office2019.

32. Genoud PA. Indice de Position SocioEconomique (IPSE). Chaire de Psychologie Clinique, Université de Fribourg, Fribourg, Switzerland; 2005.

33. Bouvard M, Cottraux J, Mollard M, Messy P, Defayolle M. Validation et analyse factorielle de l'échelle d'affirmation de soi de Rathus. Psychologie Médicale. 1986;18:759-63.

34. Inglés CJ, Hidalgo MD, Méndez FX. Interpersonal difficulties in adolescence: A new self-report measure. European Journal of Psychological Assessment. 2005;21(1):11-22.

35. Gross JJ, John OP. Facets of emotional expressivity: Three self-report factors and their correlates. Personality and Individual Differences. 1995;19(4):555-68.

36. Riggio RE. Assessment of basic social skills. Journal of Personality and Social Psychology. 1986;51(3):649-60.

37. Riggio RE, Carney DR. (2003) Social Skills Inventory manual. Redwood City, CA: Mind Garden.

38. Cronbach LJ. Coefficient alpha and the internal structure of tests. Psychometrika. 1951;16(3):297-334.

39. Guttman L. A basis for analyzing test-retest reliability. Psychometrika. 1945;42(4):567-78.

40. McDonald RP. (1999) Test homogeneity, reliability, and generalizability. In: McDonald RP, ed. Test theory: A unified treatment. Mahwah, New Jersey: Lawrence Erlbaum Associates; 1999. pp. 76-120.

41. R Development Core Team. (2014) R: A language and environment for statistical computing. Vienna, Austria: R Foundation for Statistical Computing.

42. Revelle W, Rocklin T. Very Simple Structure: An alternative procedure for estimating the opimal number of interpretable factors. Multivatiate Behavioral Research.

1979;14(4):403-14. 
43. McDonald RP. (1999) The common factor model. In: McDonald RP, ed. Test theory: A unified treatment. Mahwah, New Jersey: Laurence Erlbaum Associates; 1999. pp. 167-96. 44. Beauducel A, Wittmann WW. Simulation study on fit indexes in CFA based on data with slightly distorted simple structure. Structural Equation Modeling. 2005;12(1):41-75. 45. Fleeson W, Noftle E. The end of the person-situation debate: An emerging synthesis in the answer to the consistency question. Social and Personality Psychology Compass. 2008;2(4):1667-84.

46. Cortina JM. What is coefficient alpha? An examination of theory and applications. Journal of Applied Psychology. 1993;78(1):98-104.

47. Burleson BR, Kunkel AW, Samter W, Working KJ. Men's and women's evaluations of communication skills in personal relationships: When sex differences make a difference and when they don't. Journal of Social and Personal Relationships. 1996;13(2):201-24.

48. boyd D. (2014) It's complicated: The social lives of networked teens. New Haven: Yale University Press.

49. Lenhart A. Teens, social media \& technology overview 2015. Pew Research Center Internet and Technology2015.

50. Yau JC, Reich SM. Are the qualities of adolescents' offline friendships present in digital interactions? Adolescent Research Review. 2018;3(3):339-55.

51. Nesi J, Choukas-Bradley S, Prinstein MJ. Transformation of adolescent peer relations in the social media context: Part 2-Application to peer group processes and future directions for research. Clinical Child and Family Psychology Review. 2018;21(3):295-319. 52. Suter L, Waller G, Bernath J, Külling C, Willemse I, Süss D. JAMES: Youth, Activities, Media - Swiss Survey. Zürcher Hochschule für Angewandte Wissenschaften2018. 
Table 1.

Varimax Rotation of the Four-Factor Solution of the RECS

\begin{tabular}{|c|c|c|c|c|}
\hline Item $^{a}$ & $\begin{array}{c}\text { Factor 1 } \\
\text { Sociability }\end{array}$ & $\begin{array}{c}\text { Factor } 2 \\
\text { Self- } \\
\text { disclosure }\end{array}$ & $\begin{array}{c}\text { Factor } 3 \\
\text { Emotion } \\
\text { Decoding }\end{array}$ & $\begin{array}{c}\text { Factor } 4 \\
\text { Assertiveness }\end{array}$ \\
\hline
\end{tabular}

Real Communication Skills (RCS)

1. Meet new people

2. Invite new acquaintances to do activities

8. Propose new things to interesting people

52. People say that I have many friends

48. Prefer hanging out with a large group of friends

10. Cry in front of others

55. Rarely share my emotions ${ }^{\mathrm{b}}$

.76

.76
.76
.75
.59
.54

$\begin{array}{lll}.07 & .08 & .00\end{array}$

$\begin{array}{lll}.22 & .18 & -.04\end{array}$

11. Disclose things that scare me

28. Difficult to hide my emotions

.21

.04

$-.07$

.07

.07

.78

.76

.12

23. Disclose things that I'm ashamed of

.01

21. Sense sadness of others, even if hidden

.06

49. Skilled in identifying emotions of others

15. Rarely wrong when thinking someone is happy

.02

.06

44. Easily realize when someone is angry

.08

$-.01$

27. Pay attention to body language

24. Do not express opinions if different of that of others ${ }^{b}$

.20

$-.16$

18. Express opinion even if differs from respected person

.20

30. Friends consider as assertive

$\%$ of variance explained

Electronic Communication Skills (ECS)

.24

22. Suggest to switch to private system (chatroom)

4. Favor chat publicly with large group of people

5. Propose new things to interesting people

10. Widen circle of online friends

$\begin{array}{ll}\mathbf{. 6 7} & .08 \\ \mathbf{. 6 3} & .01 \\ \mathbf{. 6 3} & .12 \\ \mathbf{. 6 1} & .03\end{array}$

.20

.01

.06

.15

.06

$-.03$

$-.05$

$\begin{array}{rrr}.03 & .06 & -.05 \\ .15 & .14\end{array}$

.00
.04
.00
.8
8
.07
1
.27
.09
.07
.8
.09
.07
.69
.63


43. Invite new acquaintances to do activities

$\begin{array}{cccc}\mathbf{. 5 9} & .24 & .06 & -.01 \\ .12 & \mathbf{. 7 9} & .03 & .18 \\ .01 & \mathbf{. 7 7} & -.05 & .08 \\ .15 & \mathbf{. 6 8} & .26 & -.02 \\ .18 & \mathbf{. 4 7} & .15 & -.27 \\ .05 & . \mathbf{3 6} & .16 & .16 \\ .07 & .10 & \mathbf{7 6} & .04 \\ .02 & .06 & \mathbf{. 7 5} & .02 \\ .17 & .16 & . \mathbf{7 4} & -.12 \\ .13 & .06 & \mathbf{7 1} & .12 \\ .16 & .26 & . \mathbf{3 2} & .03 \\ -.13 & .02 & -.12 & \mathbf{. 8 0} \\ .09 & .12 & .06 & \mathbf{. 7 8} \\ .23 & .12 & .29 & \mathbf{. 4 8} \\ 12.26 \% & 12.55 \% & 14.38 \% & 9.26 \%\end{array}$

14. Disclose things that I'm ashamed of

31. Easily share my emotions

19. Difficult to hide my emotions

37. Write long texts

36. Easily realize when someone is angry

30. Rarely wrong when thinking someone is happy

18. Sense sadness of others, even if hidden

6. Skilled in identifying emotions of others

12. Pay attention to emoticons

33. Do not express opinions if different of that of others ${ }^{b}$

27. Tell when I disagree with someone

3. Friends consider as assertive

$$
\% \text { of variance explained }
$$

${ }^{\mathrm{a}}$ Item scale: 1 (strongly disagree) to 5 (strongly agree). ${ }^{\mathrm{b}}$ Reverse scored item. 
Table 2.

Fit Indices of Alternative Structural Models of the RECS

\begin{tabular}{|c|c|c|c|c|c|c|}
\hline Model & $\chi^{2}$ & $D f$ & CFI & RMSEA & SRMR & $\chi_{\text {diff }}^{2}$ \\
\hline \multicolumn{7}{|c|}{$\operatorname{RCS}(n=267)$} \\
\hline 1. Independent & 343.343 & 135 & .727 & .076 & .121 & \\
\hline $\begin{array}{l}\text { 2. Covariances allowed } \\
\text { Difference between }\end{array}$ & 225.956 & 129 & .873 & .053 & .062 & $117.39^{*}$ \\
\hline $\begin{array}{l}\text { Model } 1 \text { and Model } 2 \\
\text { 3. Hierarchical }\end{array}$ & 230.934 & 131 & .869 & .053 & .063 & \\
\hline $\begin{array}{l}\text { Difference between } \\
\text { Model } 2 \text { and Model } 3 \\
\text { 4. Bifactor } \\
\text { Difference between } \\
\text { Model } 2 \text { and Model } 4\end{array}$ & 151.232 & 111 & .947 & .037 & .047 & $74.724^{*}$ \\
\hline
\end{tabular}

\begin{tabular}{|c|c|c|c|c|c|c|}
\hline \multicolumn{7}{|c|}{$\operatorname{ECS}(n=234)$} \\
\hline 1. Independent & 385.189 & 135 & .731 & .089 & .153 & \\
\hline $\begin{array}{l}\text { 2. Covariances allowed } \\
\text { Difference between }\end{array}$ & 264.506 & 129 & .854 & .067 & .071 & $120.68^{*}$ \\
\hline $\begin{array}{l}\text { Model } 1 \text { and Model } 2 \\
\text { 3. Hierarchical } \\
\text { Difference between }\end{array}$ & 268.566 & 131 & .852 & .067 & .073 & 4.06 \\
\hline $\begin{array}{l}\text { Model } 2 \text { and Model } 3 \\
\text { 4. Bifactor } \\
\text { Difference between } \\
\text { Model } 2 \text { and Model } 4\end{array}$ & 181.343 & 111 & .924 & .052 & .057 & $83.163^{*}$ \\
\hline
\end{tabular}

$$
\operatorname{RECS}(n=215)
$$

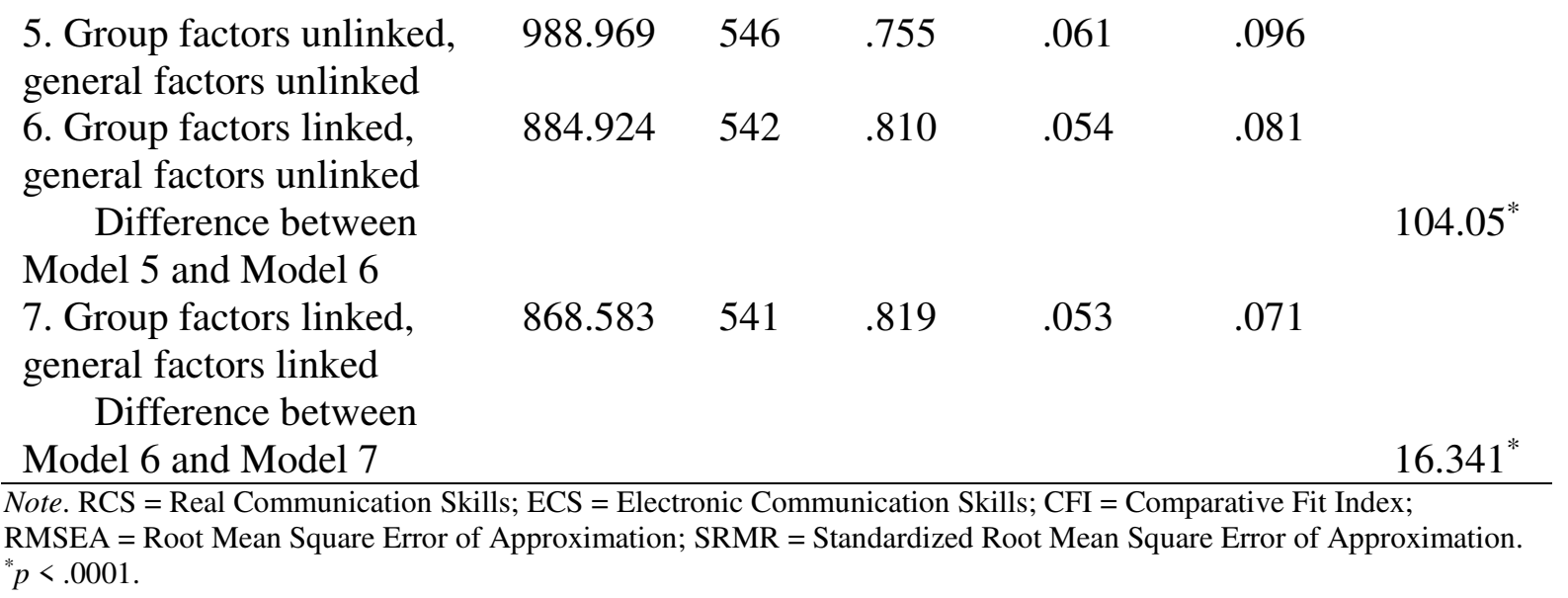


Table 3.

Internal Consistency Reliability and Correlations between the RECS and the SSI Subscales

\begin{tabular}{|c|c|c|c|c|c|c|c|c|c|}
\hline & \multicolumn{9}{|c|}{ Social Skills Inventory } \\
\hline & $\alpha$ & $\omega^{\mathrm{a}}$ & $\mathrm{EE}$ & ES & $\mathrm{EC}$ & SE & SS & $\mathrm{SC}$ & Total \\
\hline \multicolumn{10}{|l|}{ RECS } \\
\hline RCS total & .75 & .81 & $.59^{*}$ & $.45^{*}$ & $-.32^{*}$ & $.62^{*}$ & -.06 & $.51^{*}$ & $.60^{*}$ \\
\hline Sociability & .66 & & $.37^{*}$ & .22 & -.10 & $.70^{*}$ & -.11 & $.55^{*}$ & $.58^{*}$ \\
\hline Disclosure & .73 & & $.64^{*}$ & .21 & $-.59^{*}$ & .24 & .17 & .11 & .22 \\
\hline Emotion decoding & .73 & & .03 & $.60^{*}$ & .10 & .23 & .00 & .19 & $.39^{*}$ \\
\hline Assertiveness & .51 & & $.27^{*}$ & .15 & .06 & $.41^{*}$ & $-.41^{*}$ & $.57^{*}$ & $.38^{*}$ \\
\hline ECS total & .78 & .84 & $.28^{*}$ & $.34^{*}$ & -.02 & $.29^{*}$ & .05 & .22 & $.40^{*}$ \\
\hline Sociability & .71 & & .21 & .19 & .02 & $.32^{*}$ & .03 & .21 & $.34^{*}$ \\
\hline Disclosure & .62 & & $.38^{*}$ & .21 & -.21 & .19 & .10 & .07 & $.24^{*}$ \\
\hline Emotion decoding & .73 & & -.04 & $.32^{*}$ & .12 & .07 & .09 & .09 & .23 \\
\hline Assertiveness & .51 & & .23 & .20 & .05 & .20 & -.18 & $.31^{*}$ & $.28^{*}$ \\
\hline
\end{tabular}

Note. $n=200$. RCS = Real Communication Skills; ECS = Electronic Communication Skills; EE = Emotional Expressivity; $\mathrm{ES}=$ Emotional Sensitivity; $\mathrm{EC}=$ Emotional Control; $\mathrm{SE}=$ Social Expressivity; $\mathrm{SS}=$ Social Sensitivity SC = Social Control.

an bifactor models, this coefficient refers to McDonald's ${ }^{43}$ omega total coefficient, which represents the variance of each subscale that is explained by the general and domain specific factors.

${ }^{*} p<.05$ (Bonferroni-adjusted) 


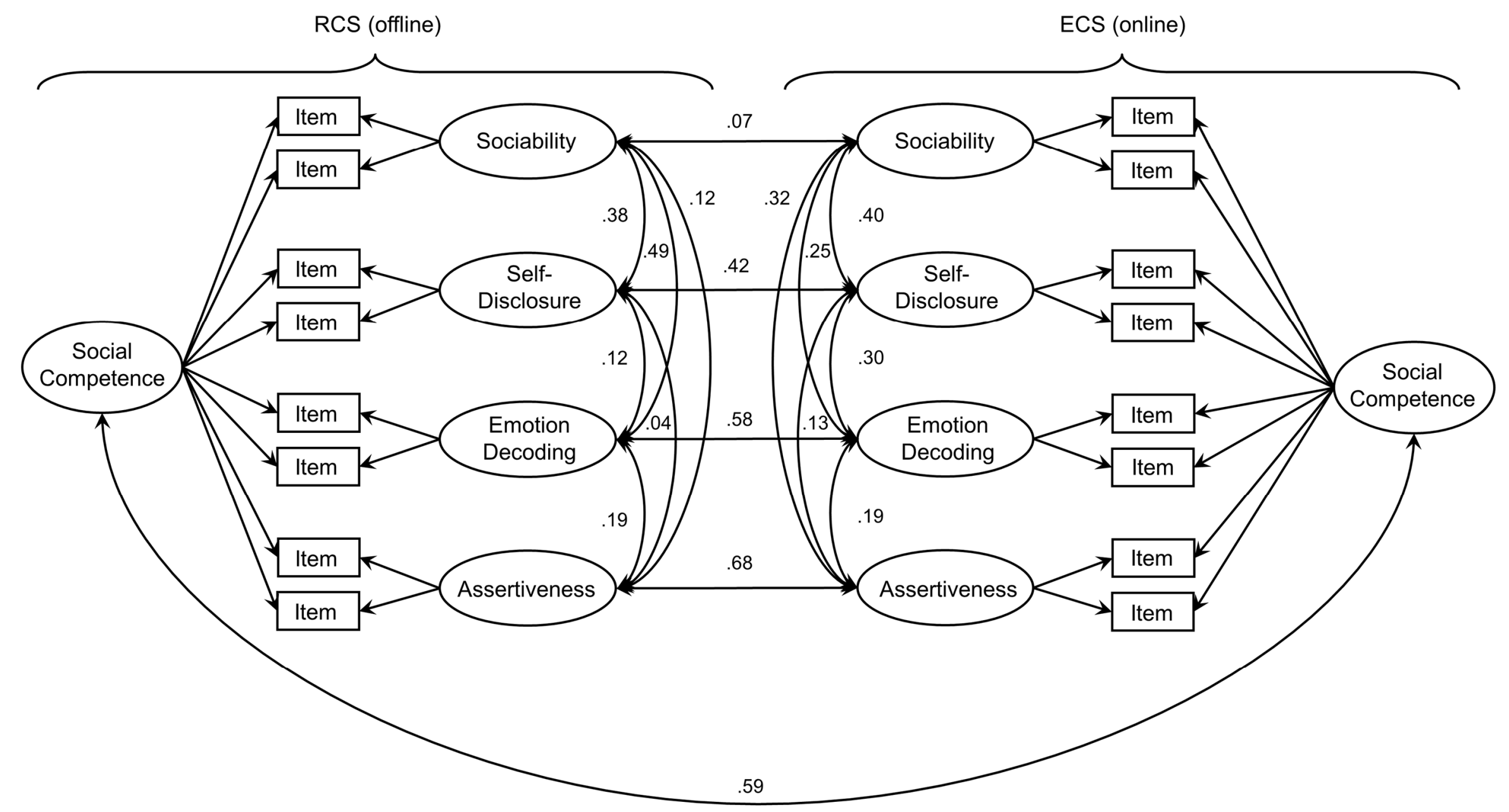

Figure 1. Standardized coefficients for the relationships between both bifactor subscales of the RECS. For clarity reasons, all 36 indicators (items) do not appear in the figure, but their position is shown schematically. 


\section{RCSi}

Toutes ces affirmations concernent ce que vous faites dans la vie réelle seulement et PAS ce que vous faites lorsque vous êtes sur internet!

Utilisez la grille pour indiquer à quel point vous êtes en accord ou en désaccord avec chacune des affirmations qui suivent.

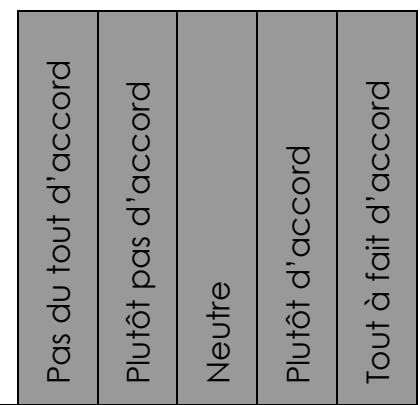

1. J'aime beaucoup faire la connaissance de nouvelles personnes.

2. II m'arrive de pleurer devant les autres.

3. Quand je crois que quelqu'un est heureux, je me trompe rarement.

4. Quand je ne suis pas d'accord avec quelqu'un de respecté, je le dis.

5. Je préfère fréquenter un large groupe d'amis plutôt qu'un groupe de deux ou trois personnes.

6. Je partage rarement mes émotions.

7. Quand quelqu'un est triste, je le vois immédiatement, même s'il essaye de le cacher.

8. Quand je suis avec mes amis, je n'exprime pas mes opinions, si elles sont différentes de celles des autres.

9. Les gens disent que j'ai beaucoup d'amis.

10. Il m'arrive souvent de raconter à un ami proche les choses qui, en secret, me font peur ou m'angoissent.

11. Quand je discute avec quelqu'un, je fais aussi attention à sa gestuelle.

12. En général, mes amis me considèrent comme quelqu'un qui sait s'affirmer.

13. Quand je viens de faire la connaissance d'une personne, j'ai souvent l'habitude de lui demander ou de lui proposer de faire des activités (p. ex. aller boire un café, parler d'un sujet précis).

14. II m'arrive souvent de raconter à une connaissance proche des choses sur moi dont j'ai honte.

15. Lorsque quelqu'un est en colère, je m'en rends facilement compte.

16. Je propose souvent de faire de nouvelles choses avec des personnes dont je viens de faire la connaissance et que je trouve intéressantes et attrayantes.

17. Parfois, j'ai de la peine à cacher mes émotions, même si j'essaye.

18. Je suis doué pour identifier les émotions des autres. 


\section{ECS}

Toutes ces affirmations concernent ce que vous faites lorsque vous êtes connecté(e) sur internet (depuis un ordinateur, un natel, un Ogo, etc...).

Utilisez la grille pour indiquer à quel point vous êtes en accord ou en désaccord avec chacune des affirmations qui suivent.

1. Quand je suis online, je préfère discuter publiquement avec beaucoup de personnes à la fois, plutôt que de rester avec peu de personnes.

2. Lorsque je discute sur internet avec une connaissance proche, j'arrive facilement à lui raconter des choses dont j'ai honte.

3. Quand un internaute est triste, je m'en rends compte immédiatement, même s'il essaye de le cacher.

4. Sur internet, si je ne suis pas d'accord avec quelqu'un, je le dis sans problème.

5. Sur internet, j'invite souvent les gens à faire certaines activités (p. ex. jeux, participer à un groupe de discussion, tests sur Facebook).

6. En utilisant les moyens de communication électronique, j'arrive facilement à raconter à un(e) ami(e) des choses qui m'angoissent ou qui me font peur en secret.

7. Quand je suis online, j'arrive facilement à identifier les émotions des autres internautes.

8. Quand je discute sur internet avec des amis, je ne donne pas mon avis s'il est différent de celui des autres.

9. Sur internet, quand je rencontre des personnes que je trouve intéressantes, je leur propose de faire d'autres activités online (p. ex. échanger des photos ou participer à des concours).

10. C'est difficile pour moi de cacher mes émotions quand je suis online.

11. Sur internet, quand je pense que quelqu'un est heureux, j'ai souvent raison.

12. Les gens avec qui je discute sur internet considèrent que je sais m'affirmer.

13. J'aime beaucoup augmenter mon cercle d'amis sur internet.

14. J'exprime facilement mes émotions quand je discute par internet.

15. Lorsque quelqu'un est en colère sur internet, je m'en rends facilement compte.

16. Sur internet, je propose souvent à plusieurs personnes que je connais de se retrouver ensemble dans un système privé (par exemple dans une room lors de chats ou dans un échange d'emails de groupe).

17. Quand je communique par internet, j'ai tendance à écrire de très longs textes.

18. Quand je discute avec quelqu'un sur internet, je fais aussi attention aux émoticônes qu'il utilise.
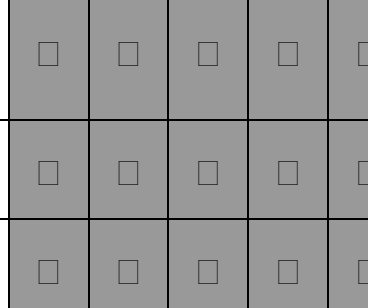


\section{RCS}

All these statements are about what you do in real life only and NOT what you do when you are on the Internet!

Use the grid to indicate how much you agree or disagree with each of the following statements.

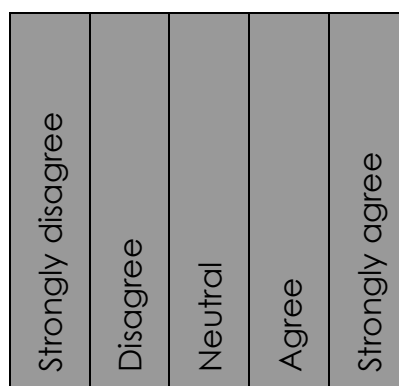

1. I really enjoy getting to know new people.

2. Sometimes, I cry in front of others.

3. When I think someone is happy, I'm rarely wrong.

4. When I disagree with someone respected, I say so.

5. I prefer to spend time with a large group of friends rather than a group of two or three people.

6. I rarely share my emotions.

7. When someone is sad, I see it immediately, even if he tries to hide it.

8. When I am with my friends, I do not express my opinions if they are different from those of others.

9. People say that I have a lot of friends.

10. I often tell a close friend about things that secretly frighten or distress me.

11. When I talk to someone, I also pay attention to their body language.

12. In general, my friends consider me as someone who knows how to assert himself.

13. When I have just met a person, I often ask or suggest activities (e.g., going for a coffee, talking about a specific topic).

14. I often tell a close acquaintance about things about myself that I am ashamed of.

15. When someone is angry, I can see that easily.

16. I often suggest doing new things to people I have just met and who I find interesting and appealing.

17. Sometimes, I have trouble hiding my emotions, even if I try.

18. I am good at identifying other people's emotions. 


\section{ECS}

All these statements are about what you do when you are connected to the Internet (from a desktop computer, from a smartphone, etc.)

Use the grid to indicate how much you agree or disagree with each of the following statements.

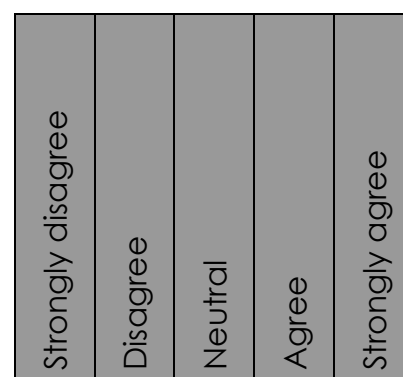

1. When I am online, I prefer to talk publicly with many people at a time, rather than staying with a few people.

2. When I chat on the Internet with a close acquaintance, I can easily tell them things I'm ashamed of.

3. When a person is sad online, I immediately realize it, even if he tries to hide it.

4. On the Internet, if I don't agree with someone, I say so without any problems.

5. On the Internet, I often invite people to do certain activities (e.g., games, participate in a discussion group, Facebook tests, etc.).

6. Through the Internet, I can easily tell a friend about things that make me anxious or frighten me in secret.

7. When I am online, I can easily identify the emotions of the other Internet users.

8. When I chat online with friends, I don't give my opinion if it is different from other people's.

9. On the Internet, when I meet people I find interesting, I suggest them to do other online activities (e.g., exchanging photos or participating in competitions).

10. It's hard for me to hide my emotions when I'm online.

11. On the Internet, when I think someone is happy, I'm often right.

12. The people I talk to online consider me as someone who knows how to assert himself.

13. I really like to increase my circle of friends on the Internet.

14. I can easily express my emotions when I chat online.

15. When someone is angry on the Internet, I can easily see that.

16. On the Internet, I often propose to several people I know to meet together in a private system (e.g., in a group chat).

17. When I communicate online, I tend to write very long texts.

18. When I talk with someone online, I also pay attention to the emoticons they use.

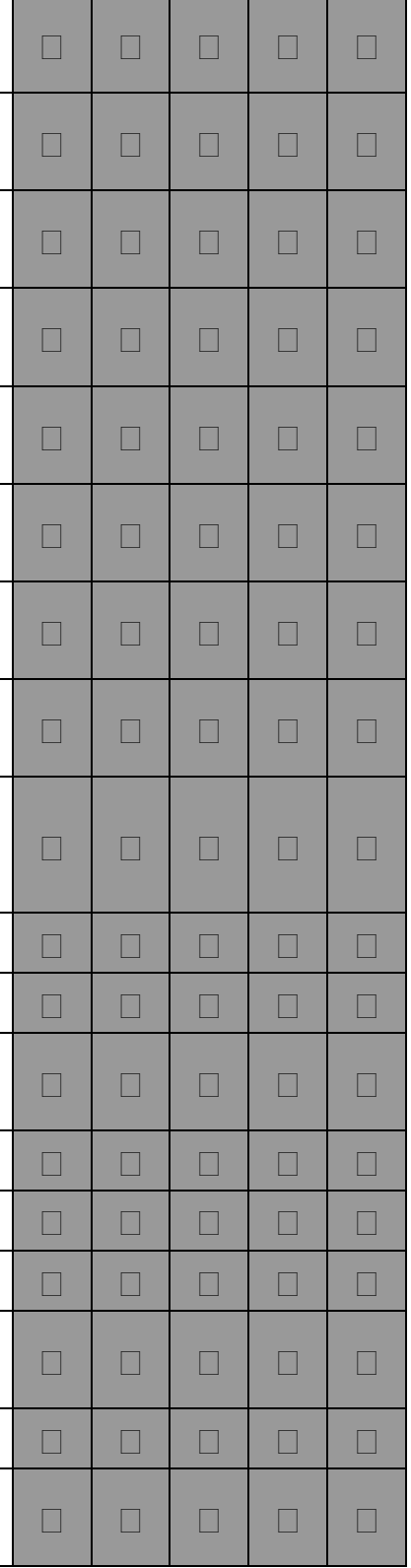

\footnotetext{
i The French version of the instrument was validated in the article. All items were translated from French to English by the authors.

Scoring RCS: Sociability = Items 1, 5, 9, 13, 16; Disclosure = Items 2, R6, 10, 14, 17; Emotion Decoding = Items 3, 7, 11, 15, 18; Assertiveness = Items 4, R8, 12. Scoring ECS: Sociability = Items 1, 5, 9, 13, 16; Disclosure = Items 2, 6, 10, 14, 17; Emotion Decoding = Items 3, 7, 11, 15, 18; Assertiveness = Items 4, R8, 12. R = reverse scored items.
} 